\title{
Occurrence of Cyanobacterial Blooms in Vojvodina Water Ecosystems
}

\author{
Simeunović, Jelica, Svirčev, Zorica' \\ Krstić, Svetislav ${ }^{2}$ \\ Lazić, Lazar $^{3}$
}

\begin{abstract}
During a brief survey (summer 2005-spring 2006) of 16 water ecosystems in Vojvodina region regarding bloom events of potentially toxic and toxic cyanobacteria species, almost $60 \%$ of investigated water bodies were found in blooming. The most dominant detected bloom forming cyanobacteria species were Aphanizomenon flos-aquae, Anabaena circinalis, A. planktonica, A. flos-aquae, Microcystis flos-aquae, M. aeruginosa, Planktothrix (Oscillatoria) rubescens, all belonging to potentially toxin or toxin production species, microcystin being the most frequently produced toxin. Following detected blooms, concentrations of chlorophyll $a$ were also indicative for a very high primary productivity of investigated localities and high algal biomass development. Detected environmental situation deserves immediate attention by authorites in charge for preserving the environmental quality. Mass presence of the potentially toxic and toxic species represents latent and real threat to human and animal health, but also an important indicator of the rapid water quality deterioration which could represent challengable obstacle for the future development of the region. It is therefore imperativelly recommended that the basic principles of WFD, monitoring in particular, be immediatelly established in the region.
\end{abstract}

Key words: Blooms, Cyanobacteria, Serbia, Vojvodina and Water ecosystems

\section{Jelica Simeunović, Zorica Svirčev \\ Department of Biology and Ecology, Faculty of Natural Sciences, Novi Sad, Serbia \\ 2 Svetislav Krstić \\ Institute of Biology, Faculty of Natural Sciences, Skopje, Macedonia \\ 3 Lazar Lazić}

Department of Geography, Tourism and Hotel Management, Faculty of Natural

Sciences, Novi Sad, Serbia

\section{Introduction}

Globally accelerated process of eutrophication of water ecosystems has made the analysis of presence, frequency and character of cyanobacterial occurrence and their eco-physiological properties, as well as their metabolic products like toxins (WHO, 1998), an invaluable element of the analysis of every water environment.

Regarding the hitherto known highly noxious effects of cyanotoxins on human and animal health, it is very expecting to conclude that every mass occurrence and development of cyanobacteria represents potential and real threat to the public health (Rapala and Lahti, 2002). Therefore, the monitoring of water ecosystems in order to detect the occurrence of mass development (blooms) of cyanobacteria through the regular biomass measurements, the character of their occurrence, the presence of potentially toxic and toxic species, the examination of their eco-physiological characteristics and metabolic activities, and through regular detecting of the presence and quantity of cyanotoxins, is a very important element in the overall water quality estimation (Chorus and Bartram, 1999). Monitoring of drinking water, recreational water bodies and drinking water reservoirs is of exceptional importance. The presence of certain cyanobacterial species and their secondary metabolites - the cyanotoxins in examined waters may result in prohibition of those water bodies for drinking water or recreational purposes (Chorus et al., 2000; Skulberg, 2005).

Since there is no regular monitoring system established in water ecosystems in Vojvodina region regarding the detection of the presence of potentially toxic and toxic cyanobacteria and cyanotoxins, conducting regular analysis aimed to create the monitoring system is of great importance. Such regularly conducted water quality analysis should represent the basis for determination of water ecosystems ecology status, perception of the impact of different factors on the water quality and detection of causes and consequences of accelerated eutrophication that is followed by mass algal and cyanobacterial develop- ment, resulting in toxin production very often.

In the light of stated circumstances, the aim of this paper was detection of toxic and potentially toxic cyanobacteria in water ecosystems of Vojvodina region and recognition of those ecosystems where mass algal blooms occur. Analysis of the other parameters of water quality, such as chlorophyll $a$ concentrations, phosphatase activity and basic physic-chemical parameters, were also conducted aimed for determination of overall ecological status and monitoring of eutrophication processes in investigated water ecosystems.

\section{Materal and mehtods}

Water samples were collected seasonally in summer 2005 to spring 2006 period, on 16 different localities in Vojvodina by means of standard sampling methods. The investigation covered different types of surface water ecosystems such as lakes (Palić, Ludoš), reservoirs (Borkovac, Zobnatica, Tavankut), channels (Jegrička, Koviljski rit, DTD-Bečej, Vrbas-DTD, Sr. Miletić-DTD, B. Gradičte-DTD) and rivers (Krivaja, TisaN. Kneževac, Begej-Sr. Itebej, Tamiš-Botoš, B. Gradište-Mrtva Tisa).

Determination of water quality and occurence of 'water blooms' were conducted by:

1. microscopy analysis of water samples for detection esspecially of potentially toxic and toxic species;

2. spectroscopy analysis of chlorophyll a concentrations (APHA, 1995) and Felfoldy (1980) method for water quality estimation by this parameter;

3. detection of phosphatase activity by Matavulj (1986);

4. visual inspection.

\section{Results and disscussion}

During 2005, water blooms were observed in 6 of 16 investigated water ecosystems (Borkovac, Palić, Ludoš, Krivaja, Srpski Miletić-DTD, Bačko Gradište-DTD) (Fig. 1). The most frequent cyanobacterial taxa dominant in these ecosystems and forming blooms were: Aphanizomenon flosaquae, Anabaena circinalis, Microcystis 


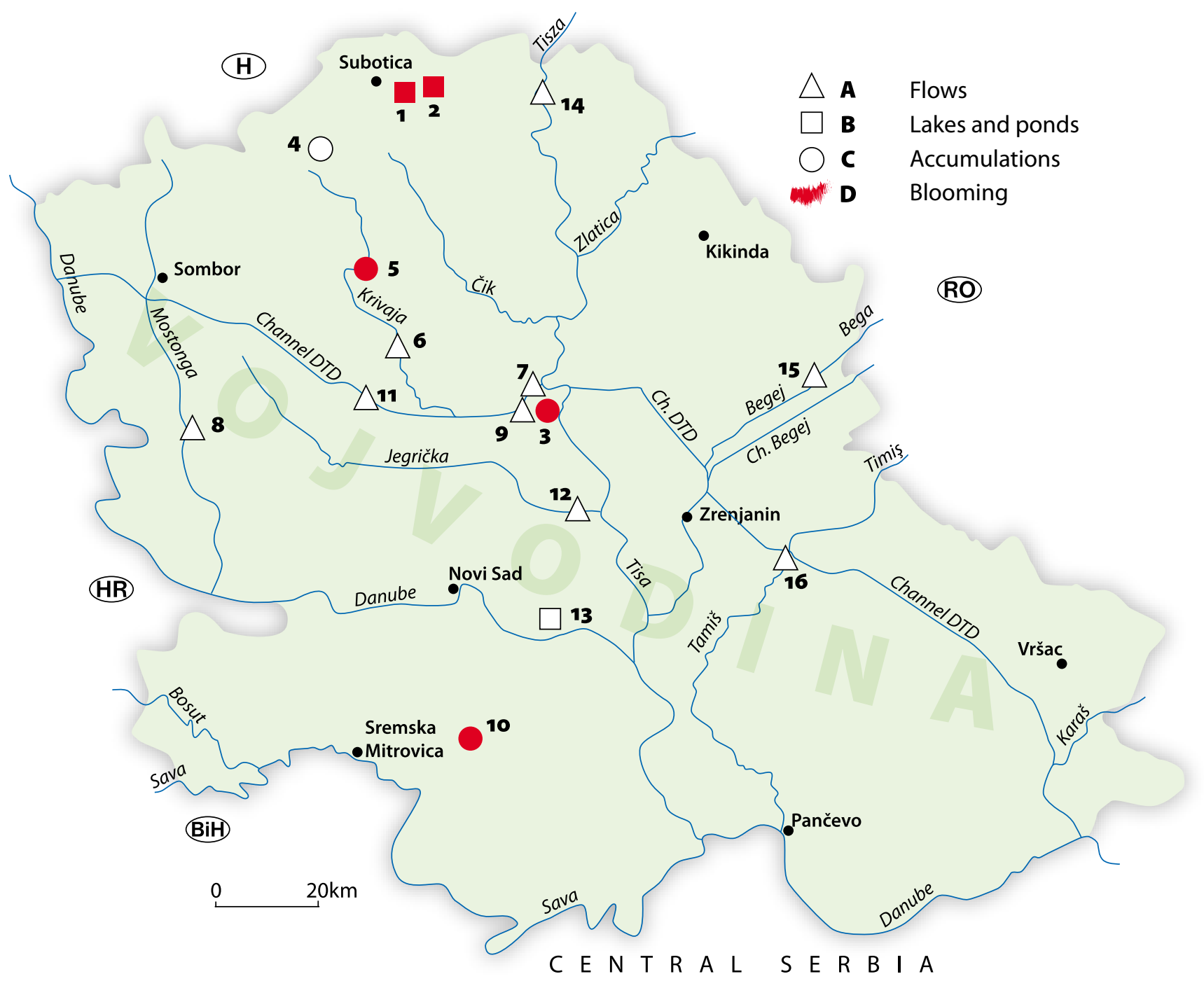

Figure 1 Cyanobacterial blooms in water ecosystems of Vojvodina region during the 2005 and 2006; Localities: 1.Palić, 2.Ludoš, 3.Mrtva Tisa, 4.Tavankut, 5.Zobnatica, 6.Krivaja, 7.DTD Bečej, 8.DTD Sr. Miletić, 9. DTD B. Gradište, 10.Borkovac, 11.DTD Vrbas, 12.Jegrička, 13.Koviljjki rit, 14.Tisa-Novi Kneževac, 15.Sr. Itebej, 16.Tamiš Botoš

flos-aquae, M. aeruginosa, Planktothrix (Oscillatoria) rubescens. All of these species belong to the group of different toxin producers, among which the most frequent are mycrocistines. Apart of these species, in specific habitats a marked presence of Anabaena flos-aquae, A. planktonica, Oscillatoria sp., Limnothrix redekei, Phormidium autumnale, Spirulina maxi$m a$ was detected, the later three belonging to the non-toxic group (Tab 1 ).

During 2005, blooms of Microcystis aeruginosa and M. flos-aquae were detected in Palić and Ludoš Lakes and DTD channel on two localities near Bečej and Bačko Gradište. Mass development of Aphanizomenon flos aquae in 2005 was observed in Borkovac reservoir and DTD channel near Bečej, while Borkovac reservoir and Lake Palić were under the mass development of Anabaena circinalis, occuring also in co-dominance with Anabaena flos-aquae in Palić and Ludoš Lakes and Zobnatica reservoir (Tab.1). Planktothrix rubescens formed mass blooms in one locality, DTD near Srpski Miletić, but was also detected in less abundance on other 6 localities.
During the spring of 2006, blooms were recorded in 4 localities (Palić, Ludoš, Krivaja, Bačko Gradište-DTD) (Fig.1). Mass development of Microcystis aeruginosa was recorded in Palić and Ludoš Lakes, while $M$. flos-aquae was dominantly present in Lake Ludoš and DTD channel near Bečej and B.Gradište (Tab 2). Aphanizomenon flos-aquae was detected in bloom on two localities, Krivaja near Srbobran and DTD near B.Gradište. Anabaena circinalis in 2006 was dominating only in Lake Palić, while Planktothrix rubescens was detected in 5 localities (Krivaja, Koviljski rit, Tisa-N. Kneževac, Tamiš-Botoš, DTD-B. Gradište) but not in a mass dominance. Lyngbya sp. belonging to the groups of toxic or potentially toxic species was recorded on 4 localities (Palić, Koviljski rit, Krivaja, Tisa-N. Kneževac).

The problem of mass development of stated cyanobacterial species is in relation of possible toxin concetration in waters since these species belong to the toxin production group. In case of Microcystis, Anabaena, Planktothrix blooms there is usually a production of hepatotoxin mycrocystin, while Anabaena and Aphanizomenon usually produce a neu- rotoxin anatoxin. Investigations inevitabely show that almost half of bloom forming cyanobacteria possess toxic production abilities (Rapala and Lahti, 2002). In freshwater ecosystems the largest number of toxic effects on biota is related exactly to cyanobacterial species Microcystis aeruginosa, Aphanizomenon flos-aquae and Anabaena flos-aquae (Gajin et al., 1999). On the other hand, toxin production may or may not be related to water bloom events, since natural communities are almost always composed of both toxin and non-toxin producing forms. Laboratory investigations confirm that the toxin production, as result of the secondary metabolism in cyanobacteria, greatly depends on the strain, culture phase, media composition, presence of nitrogen compounds, presence of predators, but most of all on stress factors such as sharp changes in $\mathrm{pH}$, temperature, light or others (Carmichael, 1986). Cyanotoxins are usually liberated from dead or injured cells and remain in water in unchanged state for a short period of time, their concentration decreasing by natural decomposition processes in the period of several days-weeks, depending of conditions. 
Table 1 Presence of potentially toxic and toxic cyanobacteria in water bodies of Vojvodina region during 2005

\begin{tabular}{|c|c|c|c|c|c|c|c|c|c|c|c|c|c|c|c|c|c|}
\hline $\begin{array}{l}\text { Cyanobacterial } \\
\text { species }\end{array}$ & Season & 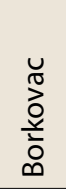 & $\frac{: U}{\pi}$ & 음 & 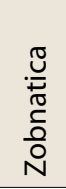 & 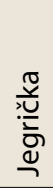 & 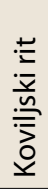 & 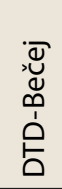 & 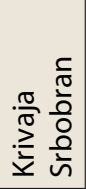 & $\begin{array}{l}n \\
0 \\
0 \\
\frac{0}{2} \\
\frac{1}{2} \\
1 \\
0 \\
0\end{array}$ & 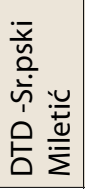 & $\frac{\frac{ \pm}{2}}{\frac{1}{0}}$ & 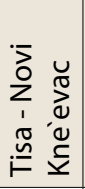 & 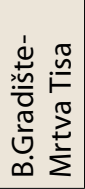 & 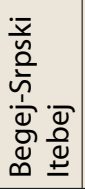 & 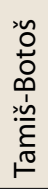 & 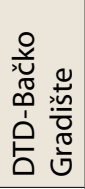 \\
\hline $\begin{array}{l}\text { Microcystis } \\
\text { aeruginosa }\end{array}$ & summer & & $+\vdash$ & $+\leftarrow$ & $+\leftarrow$ & & & $+\leftarrow$ & & & & & & & & & $+\leftarrow$ \\
\hline \multirow{2}{*}{$\begin{array}{l}\text { Microcystis flos } \\
\text {-aquae }\end{array}$} & summer & & $+\hookrightarrow$ & $+\leftarrow$ & & & & $+\leftarrow$ & & & & & & & & & \\
\hline & autumn & & + & + & & & & & & & & & & & & & \\
\hline \multirow{2}{*}{$\begin{array}{l}\text { Aphanizomenon } \\
\text { flos - aquae }\end{array}$} & summer & $+\hookrightarrow$ & & & & & & & & & & & & & & & $+\leftarrow$ \\
\hline & autumn & & & & & & & & & & & & & & & & \\
\hline \multirow{2}{*}{$\begin{array}{l}\text { Anabaena flos } \\
\text {-aquae }\end{array}$} & summer & & + & + & + & & & & & & & & & & & & \\
\hline & autumn & & + & + & & & & & & & & & & & & & \\
\hline \multirow{2}{*}{$\begin{array}{l}\text { Anabaena } \\
\text { circinalis }\end{array}$} & summer & $+\hookrightarrow$ & $+\succ$ & & & & & & & & & & & & & & \\
\hline & autumn & & + & & & & & & & & & & & & & & \\
\hline \multirow{2}{*}{$\begin{array}{l}\text { Anabaena } \\
\text { planktonica }\end{array}$} & summer & & & + & & & & & & & & & & & & & \\
\hline & autumn & & & & & & & & & & & & & & & & \\
\hline \multirow{2}{*}{$\begin{array}{l}\text { Planktothrix } \\
\text { rubescens }\end{array}$} & summer & & & + & + & & + & & & & $+\succ$ & & + & + & & & + \\
\hline & autumn & & & & & & & & & & $+\vdash$ & & & & & & \\
\hline \multirow{2}{*}{$\begin{array}{l}\text { Phormidium } \\
\text { autumnale }\end{array}$} & summer & & & & & & + & & + & + & & + & & & + & & + \\
\hline & autumn & & & & & & & & & & & & & & & & \\
\hline \multirow{2}{*}{ Oscillatoria sp. } & summer & & & & & & & + & + & + & & + & + & & + & & \\
\hline & autumn & & & & & & & & & & & & & & & + & \\
\hline \multirow{2}{*}{ Lyngbya sp. } & summer & & & & & & & & & & & & & & & & \\
\hline & autumn & & & & & & & & & & & & & & & & \\
\hline
\end{tabular}

\section{$\downarrow$ Cyanobacterial blooms}

Multiple ecological factors (ex. temperature, light, nutrient concentration, etc.) influence the development and blooming of cyanobacteria and algae, their physiological activity and hence production and liberation of toxins. In every case where one or several algal (cyanobacterial) species proliferate, that is reaching the concentrations above 10,0oo cells per milliliter, the event is termed "water bloom" (Falconer, 1998). In eu- or hyper-trophic waters, cyanobacteria mostly dominate in summer periods, as was also confirmed in this study in several investigated localities like Palić and Ludoš Lakes, Borkovac reservoir and DTD channel near Bečej and Bačko Gradište.

Research also confirmed that cyanobacterial presence even in concentrations above 1,000 cells per milliliter pose potential hazard and toxin concentration pos- sibly harmful to biota. Due to that, chlorophyll a concentration values may be another very valuable indicator for possible toxin presence in case of cyanobacterial dominance in the ecosystem.

Supporting evidence that, during the scope of this research, blooms of stated species really occurred are detected values of chlorophyll $a$ concentrations usually above $100 \mathrm{mg} / \mathrm{m}^{3}$ (Fig.2). Localities Srpski

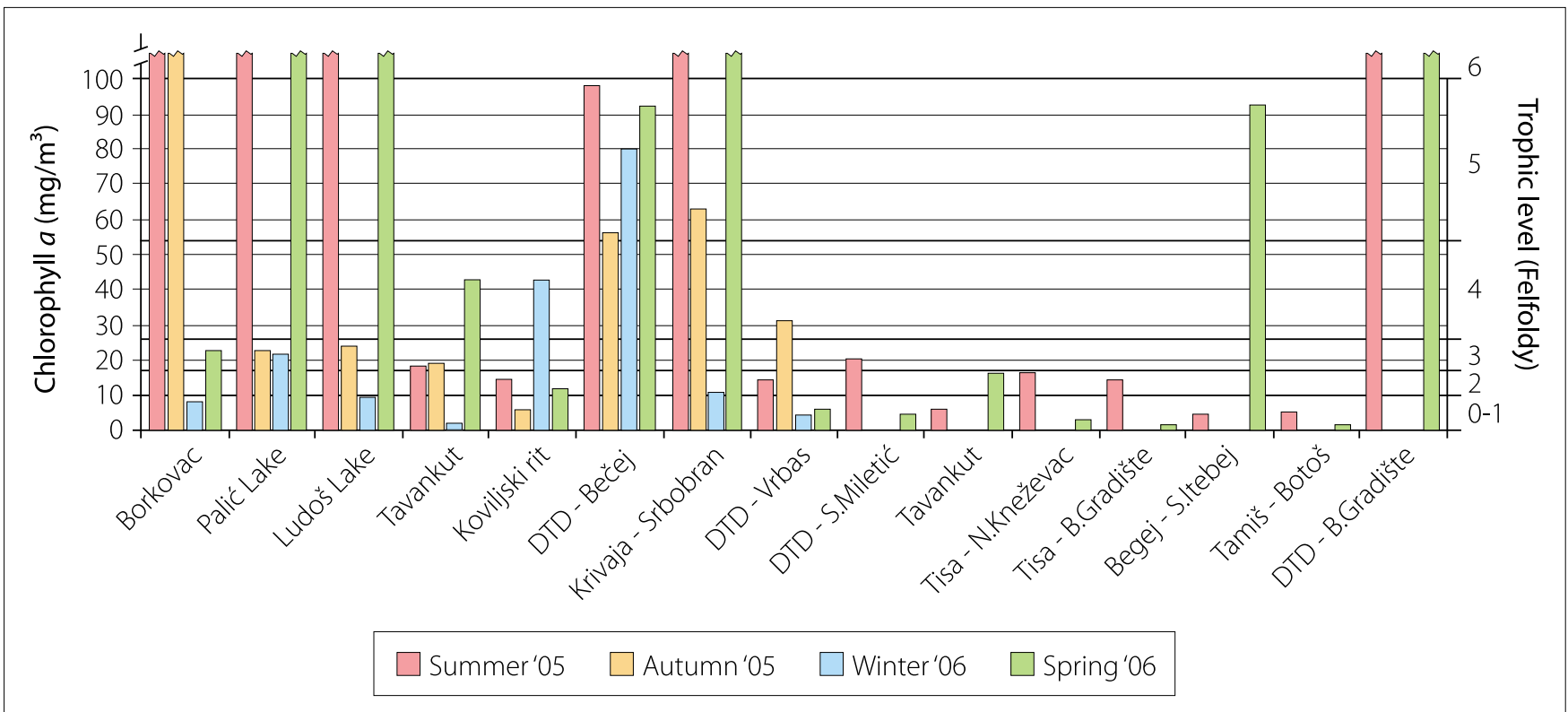

Figure 2 Concentration of chlorophyll $a$ in water bodies of Vojvodina region 
Miletić-DTD and Bačko Gradište-DTD had chlorophyll $a$ values of $144.18 \mathrm{mg} / \mathrm{m}^{3}$ and $141.51 \mathrm{mg} / \mathrm{m}^{3}$ respectivelly clasifing them in eu to polytrophic waters, while on the other sampled localities the values were high above $200 \mathrm{mg} / \mathrm{m}^{3}$ representing poly to hyper trophic waters with very high algal biomass. Esspecially important detected vallue of $1775.55 \mathrm{mg} / \mathrm{m}^{3}$ was recorded in summer on Borkovac reservoir, a highly poly trophic ecosystem.

Comparative analysis of chlorophyll $a$ concentrations on Vrbas DTD in summer $2005\left(\mathbf{1 4 . 1 2} \mathbf{~ m g} / \mathrm{m}^{3}\right)$ with the values reported for summer $2000\left(2.78 \mathrm{mg} / \mathrm{m}^{3}\right)$, leads to the obvious conclusion that there is a deterioratioin trend in water quality during this period. Contrary, results for Srpski Itebej (3.9 $\left.\mathrm{mg} / \mathrm{m}^{3}\right)$ and Tamiš Botoš $\left(7.5 \mathrm{mg} / \mathrm{m}^{3}\right)$ compared for summer period in 2003 reveil slightly decreased values (Matavulj et al., 2005).

During the spring 2006, chlorophyll a values on localities that were found in blooming were also above $100 \mathrm{mg} / \mathrm{m}_{3}$. Euto polytrophic degree of primary production was recorded on Palić, Krivaja and Bačko Gradište-DTD localities where the concentrations of chlorophyll a were $\mathbf{1 9 7 . 5 8}$ $\mathrm{mg} / \mathrm{m}^{3}, 165.54 \mathrm{mg} / \mathrm{m}^{3}, 112.14 \mathrm{mg} / \mathrm{m}^{3} \mathrm{re}-$ spectivelly, while Ludoš locality had maximum of $224.28 \mathrm{mg} / \mathrm{m}^{3}$, clearly in the frame of polytrophic level (Fig.2). Dominanting species in this events were: Microcystis flosaquae, M. aeruginosa, Anabaena circinalis, Aphanizomenon flos-aquae.

During the investigated period, values for chlorophyll a concentrations detected on the other localities were much lower. Localities B. Gradište-Mrtva Tisa, TamišBotoš $\left(\mathbf{1}, 34 \mathrm{mg} / \mathrm{m}^{3}\right)$ and Tisa-N. Kneževac $\left(2,67 \mathrm{mg} / \mathrm{m}^{3}\right)$ presented an ologotrophic level. Oligo-mesotrophic levels were detected on Vrbas-DTD $\left(5.34 \mathrm{mg} / \mathrm{m}^{3}\right), \mathrm{Sr}$. Miletić-DTD $\left(4,01 \mathrm{mg} / \mathrm{m}^{3}\right)$ and Sr. ItebejBegej $\left(4.00 \mathrm{mg} / \mathrm{m}^{3}\right)$. Mesotrophic waters were recorded on lokalities Jegrička (12,02 $\left.\mathrm{mg} / \mathrm{m}^{3}\right)$, Koviljski rit $\left(\mathbf{1 1}, 44 \mathrm{mg} / \mathrm{m}^{3}\right)$ and Tavankut $\left(16,02 \mathrm{mg} / \mathrm{m}^{3}\right)$, meso-eutrophic quality level $\left(\mathbf{2 2}, 70 \mathrm{mg} / \mathrm{m}^{\mathbf{3}}\right)$ was detected in Borkovac reservoir, and eutrophic was Bečej-DTD locality (92,12 $\mathbf{~ m g} / \mathrm{m}^{\mathbf{3}}$ ) (Fig.2).

In summary, localities Borkovac, Palić, Ludoš, DTD Bečej, Krivaja Srbobran, Bač. Gradište DTD have very high degree of primary production and consequently wast quantities of algal biomass. The lowest eutrophication level was recorded on Jegrička, Sr. Itebej and Tamiš Botoš localities.

Results obtained for phosphatase activity (IFA) during 2005 in the investigated ecosystems reveal the highest values in waters of Borkovac locality, mostly pronounced in the summer period (95). Compared to significantly lower values for the other investigated seasons, they may point out to enhanced disturbances of biota mutual relationships in this ecosystem. Mass amounts of biodegradable organic matter in the ecosystem is a basis for rapid mineralization processes, oxygen depletion and consequently directly responsible for profoundly negative impact on biota (Fig.3).

Surface waters in Vojvodina geographical region undergo intensive antrophogenic pressure, basically manifested through accelerated eutrophication processes, even during the last 25 years (Fig4., Simeunovic et al., 2006). Presented results in this paper clearly emphasize that almost $40 \%$ of investigated water ecosystems were found in state of high primary production, ranging from eu to hypertrophic conditions and followed by a massive algal development, expressed in chlorophyll $a$ concentrations. A very small number of investigated ecosystems were found in state of "good" (according to WFD, 200o) water quality, and only two showing a comparative decrease of basic eutrophication parameters over time. Having in mind that the observed algal blooms were almost in all cases dominated by cyanobacteria, a very well documented toxin producing species, overall environmental quality of investigated water ecosystems fundamentally limits their designed exploatation patterns and poses a significant threat to human or do-

Table 2 Presence of potentially toxic and toxic cyanobacteria in water bodies of Vojvodina region during 2006

\begin{tabular}{|c|c|c|c|c|c|c|c|c|c|c|c|c|c|c|c|c|c|}
\hline $\begin{array}{l}\text { Cyanobacterial } \\
\text { species }\end{array}$ & Season & 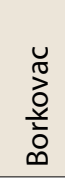 & $\frac{. u}{\bar{\sigma}}$ & $\begin{array}{l}\text { n. } \\
\frac{0}{0} \\
3\end{array}$ & $\begin{array}{l}0 \\
0 \\
0 \\
0 \\
0 \\
0 \\
0\end{array}$ & 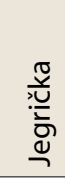 & 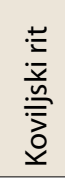 & 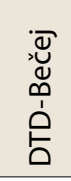 & 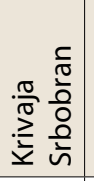 & $\begin{array}{l}\frac{n}{0} \\
\frac{0}{2} \\
\sum^{2} \\
0 \\
0\end{array}$ & 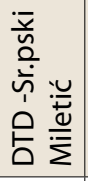 & 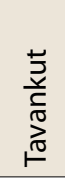 & 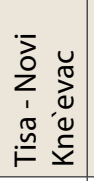 & 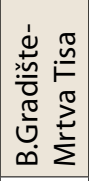 & 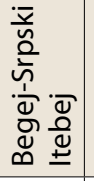 & 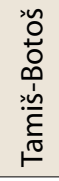 & 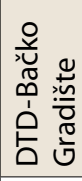 \\
\hline \multirow{2}{*}{$\begin{array}{l}\text { Microcystis } \\
\text { aeruginosa }\end{array}$} & winter & & & & + & & & & & & & & & & & & + \\
\hline & spring & & $+\hookrightarrow$ & $+\hookrightarrow$ & & & & & & & & & & & & & \\
\hline \multirow{2}{*}{$\begin{array}{l}\text { Microcystis flos } \\
\text { - aquae }\end{array}$} & winter & & & & & & & & & & & & & & & & \\
\hline & spring & & & $+\hookrightarrow$ & + & + & & + & & & & & & & & & $+\hookrightarrow$ \\
\hline \multirow{2}{*}{$\begin{array}{l}\text { Aphanizomenon } \\
\text { flos - aquae }\end{array}$} & winter & & & & & & & & & & & & & & & & \\
\hline & spring & & & + & + & & & + & $+\hookrightarrow$ & & & & + & + & & & $+\hookrightarrow$ \\
\hline \multirow{2}{*}{$\begin{array}{l}\text { Anabaena flos } \\
\text { - aquae }\end{array}$} & winter & & & & & & & & + & & & & & & & & \\
\hline & spring & & + & & & & & & & & & & & & & & \\
\hline \multirow{2}{*}{$\begin{array}{l}\text { Anabaena } \\
\text { circinalis }\end{array}$} & winter & & & & & & & & & & & & & & & & \\
\hline & spring & & $+\downarrow$ & & & & & & & & & & & & & & \\
\hline \multirow{2}{*}{$\begin{array}{l}\text { Anabaena } \\
\text { planktonica }\end{array}$} & winter & & & & & & & & & & & & & & & & \\
\hline & spring & & & & & & & & & & & & & & & & \\
\hline \multirow{2}{*}{$\begin{array}{l}\text { Planktothrix } \\
\text { rubescens }\end{array}$} & winter & & & & & & + & & + & & & & + & & & + & + \\
\hline & spring & & & & & & & & & & & & & & & & \\
\hline \multirow{2}{*}{$\begin{array}{l}\text { Phormidium } \\
\text { autumnale }\end{array}$} & winter & & & & & & + & + & + & & & & & & + & & \\
\hline & spring & & & & + & & + & + & + & & + & + & & + & + & & + \\
\hline \multirow{2}{*}{ Oscillatoria sp. } & winter & + & & & & & & + & & & & + & + & & & + & + \\
\hline & spring & + & & & + & + & + & & & & + & + & & + & + & + & \\
\hline \multirow{2}{*}{ Lyngbya sp. } & winter & & + & & & & + & & + & & & & + & & & & \\
\hline & spring & & & & & & & & & & & & & & + & & \\
\hline \multirow{2}{*}{ Spirulina maxima } & winter & & & & & & & & & & & & & & & & \\
\hline & spring & & & + & & & & & & & & + & & & & & \\
\hline \multirow{2}{*}{$\begin{array}{l}\text { Limnothrix } \\
\text { redekei }\end{array}$} & winter & & & & & & & + & + & & & & & & & & + \\
\hline & spring & & & & & & & + & & & & & & + & & & + \\
\hline
\end{tabular}




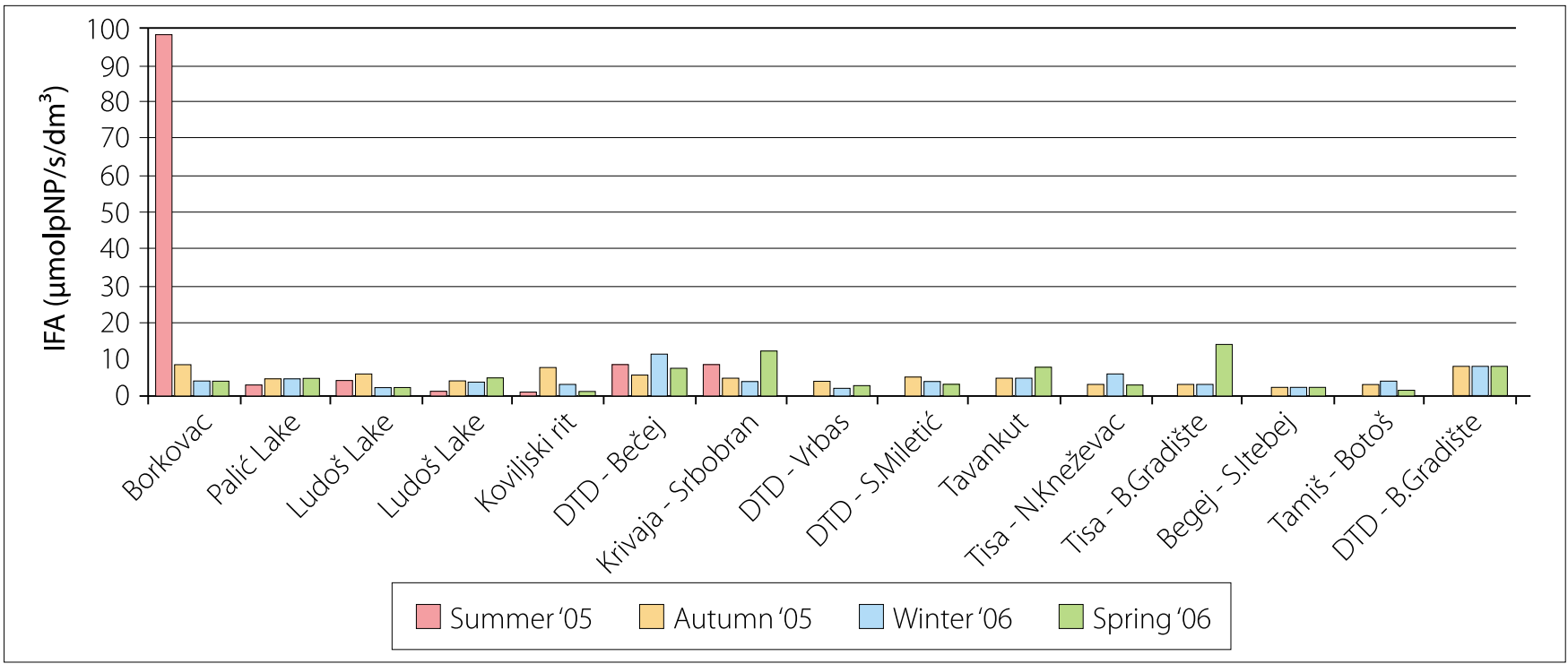

Figure 3 Phosphatase activity in water ecosystems of Vojvodina region

mestic animals' health. The only logical solution to this problem is an immediate action in a sense of sustainable development approach of Vojvodina region and implementation of EU Water Framework Directive as the basic legislative method for preserving and improving the water quality of defined ecosystems in the framework of the River Basement geographical regions and Management Plans.
The Water Framework Directive (or the Directive 2000/60/EC of the European Parliament and of the Council of 23 October 2000 establishing a framework for Community action in the field of water policy)

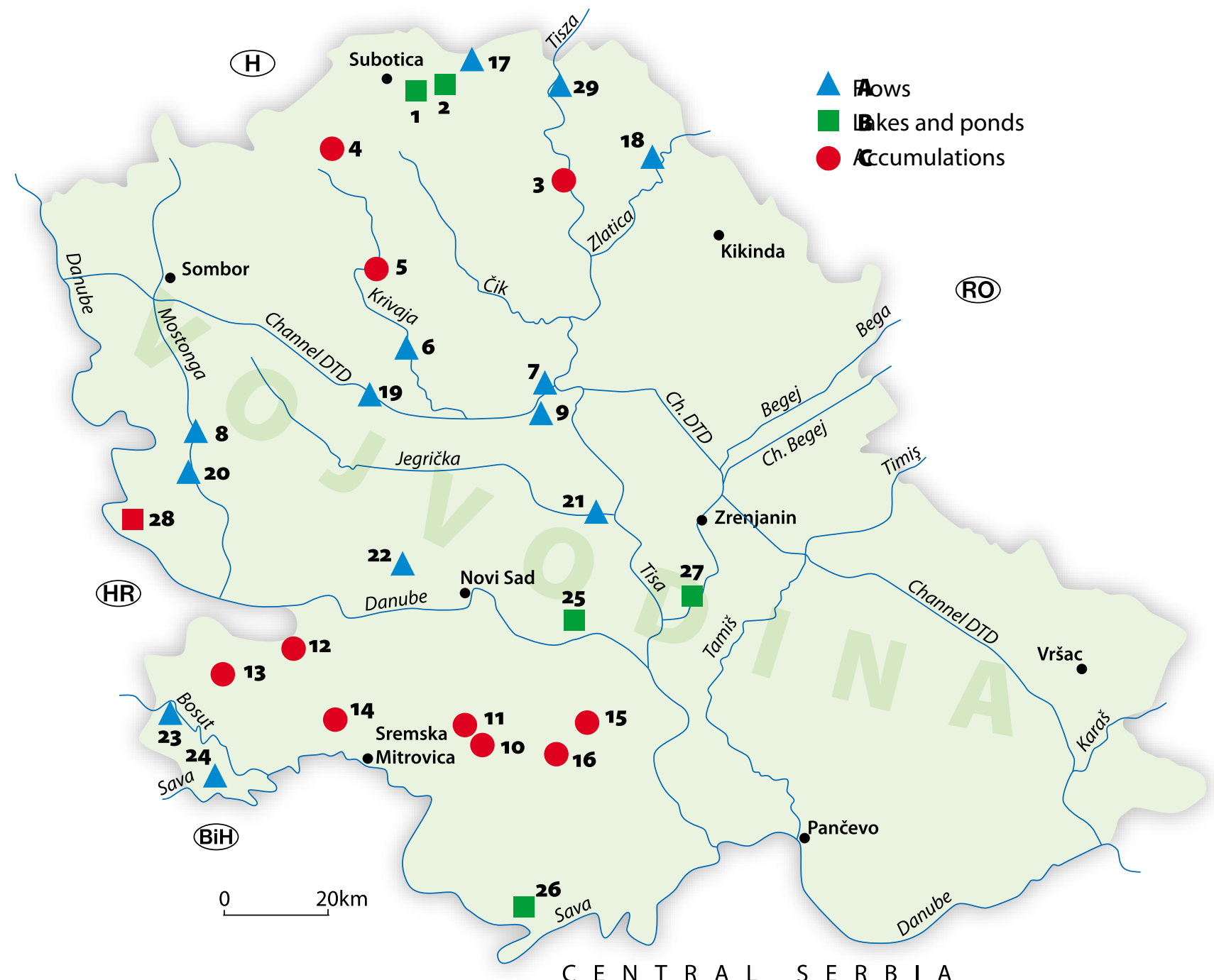

Figure 4 Cyanobacterial blooms in water ecosystems of Vojvodina region during the last 25 years; Locations: 1. Palić, 2. Ludoš, 3. Tisa, 4. Tavankut, 5. Zobnatica, 6. Krivaja, 7. DTD - Bečej, 8. DTD - Srpski Miletić, 9. DTD - Bačko Gradište, 10. Borkovac, 11. Krajkovac, 12. Sot, 13. Moharač, 14. Međeš, 16. Šelovrenac, 17. Kereš, 18. Zlatica, 19. DTD - Vrbas, 20. DTD - Bač, 21. Jegrička, 22. DTD - Novi Sad, 23. Bosut - Batrovci, 24. Studva - Morović, 25. Koviljski rit, 26. Obedska bara, 27. Carska bara, 28. Provala, 29. Tisa - Novi Kneževac - Ljukovo 
is a document issued by EU Commission as a measure against overwhelming indications that water ecosystems in Europe are in the state of continual deterioration of water quality and a result of "a process of more than five years of discussions and negotiations between a wide range of experts, stakeholders and policy makers". The Directive establishes a framework for the protection of all waters (including inland surface waters, transitional waters, coastal waters and groundwater) which:

- Prevents further deterioration of, protects and enhances the status of water resources;

- Promotes sustainable water use based on long-term protection of water resources;

- Aims at enhancing protection and improvement of the aquatic environment through specific measures for the progressive reduction of discharges, emissions and losses of priority substances and the cessation or phasing-out of discharges, emissions and losses of the priority hazardous substances;

- Ensures the progressive reduction of pollution of groundwater and prevents its further pollution;

- Contributes to mitigating the effects of floods and droughts.

The Key Objective of WFD is in Achieving good water status for all waters by 2015.

One of the key elements of WFD is the monitoring of "the water bodies". Article 8 of the Directive establishes the requirements for the monitoring of surface water status, groundwater status and protected areas. Monitoring programmes are required to establish a coherent and comprehensive overview of water status within each river basin district. The programmes have to be operational at the latest by 22 December 2006, and must be in accordance with the requirements of Annex $\mathrm{V}$ of the Directive.

Annex $\mathrm{V}$ indicates that monitoring information from surface waters is required for:

- The classification of status. (Note: Member States must provide a map for each river basin district in their territory illustrating the classification of the ecological and chemical status of each body of water using the colour-coding system specified by the Directive.)

- Supplementing and validating the Annex II risk assessment procedure;

- The efficient and effective design of future monitoring programmes;

- The assessment of long-term changes in natural conditions;

- The assessment of long-term changes resulting from widespread anthropogenic activity;

- Estimating pollutants loads transferred across international boundaries or discharging into seas;
- Assessing changes in status of those bodies identified as being at risk in response to the application of measures for improvement or prevention of deterioration;

- Ascertaining causes of water bodies failing to achieve environmental objectives where the reason for failure has not been identified;

- Ascertaining the magnitude and impacts of accidental pollution;

- Assessing compliance with the standards and objectives of Protected Areas;

- Quantifying reference conditions (where they exist) for surface water bodies.

Central position of the monitroing system in WFD (WFD-Guidance Document No 7; Fig. 5) is based on several Quality Elements for each water body, for lakes and reservoirs being:

- Hidromorphological - Hidrological regime, Morphological conditions

- Biological - Phytoplankton, Phytobenthos, Zoobenthos, Fish, Macrophytes

- Physico-chemical - Thermal conditions, Salinity, Acidification status, Nutrient sonditions, Transparency, Oxygen conditions

- Chemical - Specific synthetic and Specific Non-synthetic pollutants

Proposed monitoring system should be based on:

1. Operational Monitoring of surface waters - Establish the status of those bodies identified as being at risk of failing to meet their environmental objectives; and Assess any changes in the status of such bodies resulting from the programmes of measures. Operational monitoring (or in some cases investigative monitoring) will be used to establish or confirm the status of bodies thought to be at risk. Therefore, it is operational monitoring that will produce the environmental quality ratios used for status classification for those water bodies included in operational monitoring. It is highly focused on parameters indicative of the quality elements most sensitive to the pressures to which the water body or bodies are subject.

2. Investigative monitoring - Investigative monitoring may also be required in specified cases. These are given as: where the reason for any exceedences (of Environmental Objectives) is unknown; where surveillance monitoring indicates that the objectives set under Article 4 for a body of water are not likely to be achieved and operational monitoring has not already been established, in order to ascertain the causes of a water body or water bodies failing to achieve the environmental objectives; or to ascertain the magnitude and impacts of accidental pollution.
3. Surveillance monitoring-Aassess the long term changes in natural conditions and long term changes resulting from widespread anthropogenic activity. The minimum frequencies given in the Directive may not be adequate to achieve an acceptable level of confi dence and precision in this assessment. It may therefore be necessary to increase the frequencies of at least some surveillance monitoring parameters and monitor more than once every sixth year at those surveillance sites designed to detect long-term changes.

Key Biological Quality Elements for lakes and reservoirs - the assessment of phytoplankton diversity, abundance and biomass as fundamental importance in lakes and reservoirs (Willén, 200o). Phytoplankton growth and distribution is influenced rapidly by physico-chemical changes and excessive blooms of phytoplankton are considered evidence of eutrophication. Chlorophyll a concentrations can provide a good indicator of phytoplankton biomass and is often a major component of trophic state indices. Also, Krstic et al. (in press) point out that monitoring of algal (cyanobacteria and diatoms) species composition and abundance is the most reliable method in immediate estimation the water quality and long term water monitoring systems in the WFD-River Basin Concept.

Additional monitoring is required for drinking water abstraction points and habitat and species protection areas. However the register or registers of protected areas also includes areas designated as bathing waters under Directive $76 / 160 / \mathrm{EEC}$, as vulnerable zones under Directive 91/676/EEC and areas as sensitive under Directive 91/271/ EEC. These latter Directives also have monitoring and reporting requirements.

\section{Conclusions}

During investigated period, cyanobacterial blooms were recorded in 6 water ecosystems in 2005 and in 4 in 2006 of the total of 16 water bodies in Vojvodina region. The most dominant detected bloom forming cyanobacteria species were Aphanizomenon flos-aquae, Anabaena circinalis, A. planktonica, A. flos-aquae, Microcystis flos-aquae, M. aeruginosa, Planktothrix (Oscillatoria) rubescens, all belonging to potentially toxin or toxin producing species, microcystin being the most frequently produced toxin.

Following detected blooms, concentrations of chlorophyll $a$ were also indicative for a very high primary productivity of investigated localities and high algal biomass development.

Water quality and overall state of investigated ecosystems regarding eutrophication occurence and proliferation points out 6 localities in 2005 detected as eu, poly or even hyper trophic level depending on 


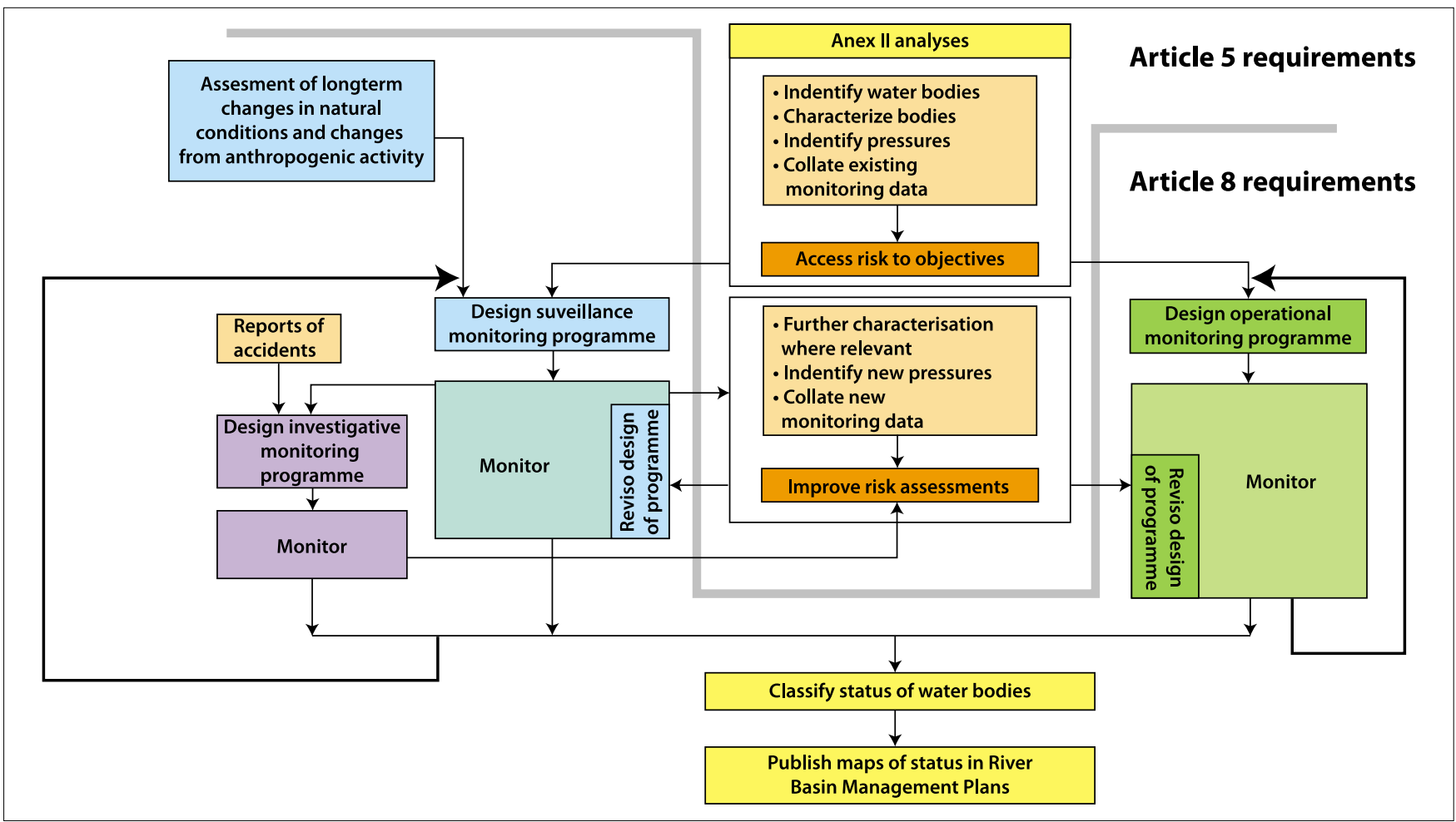

Figure 5 Schematic diagram illustrating the relationship between Article 5 and Article 8 of WFD in the design of surface water monitoring programmes

investigated season. The rest of investigated localities in 2005 were on oligo, oligomeso or meso trophic level.

Investigations in spring 2006 reveiled values for above $100 \mathrm{mg} / \mathrm{m}^{3}$ for chlorophyll $a$ on localities were the blooms were detected, Lake Ludoš having the highest value of $224.28 \mathrm{mg} / \mathrm{m}^{3}$.

This short survey of algal and cyanobacterial bloom episodes in surface waters of Vojvodina region deserves immediate attention by authorites in charge for preserving the environmental quality. Detected presence in mass development of the potentially toxic and toxic species represents latent and real threat to human and animal health, but also an important indicator of the rapid water quality deterioration which could represent challengable obstacle for the future development of the region. It is therefore imperativelly recommended that the basic principles of WFD, monitoring in particular, should be immediatelly established by forming of expert reserach teams, composed of geographers (geologists, hydrogeologists), biologists and chemists who will delineate the water bodies, postulate the monitoring system and trace the path for establishing WFD in Vojvodina region. Otherwise, as the occurence of water blooms in the past clearly shows, this important region will be left without "good quality" water ecosystems in future as one of the main obstacles in achieving the prosperous sustainable development.

\section{References}

An J.,Carmichael,W.W. 1994.Use of colorimetric protein phosphatase inhibi- tion assay and enzyme linked immuno sorbent assay for the study of microcystins and nodularins. Toxicon 32, 1495-1507.

APHA 1995. Standard methods for the examination of water and wastewater. 19th edition. Washington, 1995.

Carmichael, W.W. 1986. Algal toxins. Advances in Botanical Research 12: 47-99.

Chorus I., Bartram, J. 1999. Toxic cyanobacteria in water. WHO, England.

Chorus, I., Falconer, R., Henry, J. Salas, Bartram, J. 2000. Health risks caused by freshwater cyanobacteria in recreational waters. Journal of Toxicology and Environmental Health Part B: Critical Reviews: 323-347.

Falconer, I.R. 1998. Algal Toxins and Human Health. The Handbook of Environmental Chemistry 5. Part C Quality and Treatment of Drinking Water II (ed.) Hrubec J., Springer-Verlag Berlin Heidelberg, pp. 55-82.

Felföldy, L. 1980. A biológiai vizminösités. 3. javitott és bövitte kiadás. Vizugyi Hydrobiologicalgia 9. Budapest.

Gajin, S., Matavulj, M. 1999. Mikroalge kao izvor biološki aktivnih materija. U knjizi: Fiziološki aktivne materije algi, gljiva i viših biljaka. Univerzitet u Novom Sadu, pp. 62-67.

Krstic, S., Svirčev, Z., Levkov, Z., Nakov, T. in press. Selecting appropriate bioindicator regarding the WFD guidelines for freshwaters-a Macedonian experience. Aquatic Sciences.

Matavulj, M. 1986. The nonspecific phosphomonoester-hydrolases of microorganisms and their significance in phosphorus cy- cle in aquatic environments". (In Serbian) Ph.D. Thesis, University of Zagreb.

Rapala, J., Lahti, K. 2002. Methods for Detection of Cyanobacterial Toxins. In: Detection Methods for Algae, Protozoa and Helminths in Fresh and Drinking Water, F. Palumbo, G. Ziglio, A. Van der Beken (eds) J. Wiley and Sons, Chapter 7, pp. 107-132.

Simeunović, J., Svirčev Z., Čađo S., Subakov-Simić G. 2006. The cyanobacterial blooms in water bodies of Vojvodina region. The International Meeting „Danubius Pannonico Mysicus", September, Novi Sad. Abstract Book: 37.

Skulberg, O. 2005. Cyanobacteria/cyanotoxin research-Looking back for the future. Special Issue:6th International Conference on Toxic Cyanobacteria, In: Environmental Toxicology (ed. Sivonen K.), Volume 20, 220-228.

WFD (2000): Directive 2000/60/EC - Water Framework Directive. Official Journal of EU Communities, 21.12.200o, pp. 1-72.

WFD (2000): Common implementation strategies of WFD - Guidance Document No 7: Monitoring under WFD. EU Publishers 2003, pp 1-154.

WHO (1998): Guidlines for Safe Recreationalwater Environments: Coastal and Freshwaters. Draft for consultations, World Health Organization, Geneva.

Willen, E. 200o. Phytoplankton in Water Quality Assessment - An Indicator Concept. In: Heinonen, P., Ziglio, G. \& Van der Beken, A. (Eds.). Hydrological and Limnological Aspects of Lake Monitoring. John Wiley \& Sons, Ltd. Chichester, pp. 58-8o. 